n.tronos

glyndŵn

Glyndŵr University

Glyndŵr University Research Online

$11-1-2008$

\title{
A comparative study of some properties of cassava (Manihot esculenta, Crantz) and cocoyam (Colocasia esculenta, Linn) starches
}

Peter A. Williams

Glyndwr University, p.a.williams@glyndwr.ac.uk

Louis M. Nwokocha

Ndusbisi A. Aviara

Chandra Senan

Follow this and additional works at: http://epubs.glyndwr.ac.uk/cwsp

Part of the Polymer Chemistry Commons

The article was published by Elsevier and can be found at www.sciencedirect.com Copyright (C) 2008 Elsevier Ltd

\section{Recommended Citation}

Nwokocha, L.M., Aviara, N.A. , Senan, C., \& Williams, P.A. (2009) 'A comparative study of some properties of cassava (Manihot esculenta, Crantz) and cocoyam (Colocasia esculenta, Linn) starches'. Carbohydrate Polymers, 76( 3), 362-367

This Article is brought to you for free and open access by the Materials Science at Glyndwir University Research Online. It has been accepted for inclusion in Centre for Water Soluble Polymers by an authorized administrator of Glyndŵr University Research Online. For more information, please 


\title{
A comparative study of some properties of cassava (Manihot esculenta, Crantz) and cocoyam (Colocasia esculenta, Linn) starches
}

\author{
Louis M. Nwokocha ${ }^{1}$; Ndubisi A. Aviara ${ }^{2}$; Chandra $\operatorname{Senan}^{3}$ and P.A. Williams ${ }^{3}$ \\ ${ }^{1}$ Department of Chemistry, University of Ibadan, Ibadan, Nigeria \\ ${ }^{2}$ Department of Agricultural and Environmental Resources Engineering, University of \\ Maiduguri, Maiduguri, Nigeria \\ ${ }^{3}$ Center for Water Soluble Polymers, Glyndwr University, Wrexham, LL11 2AW, UK.
}

\begin{abstract}
Some properties of cassava and cocoyam starches were studied and compared with a view to determining the functional applications in food systems for which they are suitable. The starches were compared in terms of their microscopic, thermal, physicochemical and rheological properties. Microscopy revealed smaller granule sizes of cocoyam starch compared with cassava. The amylose content was higher in cocoyam starch (33.3\%) than in cassava starch (29.3\%). Gelatinization in cassava starch occurred at a lower temperature range $\left(60.11^{\circ}-72.67^{\circ} \mathrm{C}\right)$ compared with cocoyam $\left(72.96^{\circ}-\right.$ $80.25^{\circ} \mathrm{C}$ ) with the endothermic gelatinization enthalpy higher in cocoyam. The swelling power and solubility patterns indicated lower relaxation temperature, higher swelling and solubilization rates in cassava starch compared with cocoyam starch. The pasting characteristics of $8 \%$ (db, dry basis) starch slurry showed that cassava had higher peak viscosity but lower stability and setback ratios compared with cocoyam. This indicates that cocoyam starch paste is better in withstanding processing conditions and would present a superior thickening characteristic than cassava starch paste. The flow properties of both starch pastes showed non-Newtonian behaviour and could be best described by
\end{abstract}


the Herschel-Bulkley model. The rate index and yield stress of cocoyam starch paste was higher than that of cassava. The storage modulus of cocoyam starch paste was higher than that of cassava indicating that cocoyam starch paste was more rigid than cassava starch paste. Cassava starch paste exhibited higher paste clarity and freeze-thaw stability than cocoyam starch paste. The properties of cassava and cocoyam starches dictate their food applications.

Key words: Cassava, cocoyam, starch, pasting properties, rheological properties, paste clarity, freeze-thaw stability

\subsection{Introduction}

Cassava and cocoyam are important food crops in the tropics. Nigeria is a world-leading producer of cassava (FAOSTAT, 2001). However, despite the high production level, supply has not matched demand; this is because cassava serves both as a staple and an industrial raw material (Nweke, 2004). There is therefore need to expand the production of other carbohydrate-rich crops to provide for an alternative substitute of cassava in food and industry. Cocoyam is a promising food crop which can be produced on large scale in Nigeria (CBN, 1995). From both cassava and cocoyam, a large amount of starch is usually isolated and consumed in its colloidal form as 'fufu'. For these two starch types to be viable alternatives, a good understanding of their properties is important. Presently, the Government is placing emphasis on conversion of cassava into starch. Hence the production of starch from cassava and cocoyam for food and industrial use would be a commercially viable venture in Nigeria. The performance of a given starch in any application is governed by its physicochemical properties. Starches from different sources are known to differ in their physical and chemical properties. These differences 
are believed to arise from difference in amylose/amylopectin ratio in the starch granule, the characteristics of each fraction in terms of molecular weight, length/degree of branching and the physical manner in which these constituents are arranged within the starch granules, and the presence of naturally occurring non carbohydrate impurities (Leach, 1965). The physicochemical properties of starch are therefore an important consideration because they determine the use of any starch (Salehuzzman et al, 1992). A comparative examination of the properties of cassava and cocoyam starches is therefore important in understanding their similarities and differences in behaviour in food and industrial application. The physicochemical properties important in most applications include gelatinization temperature, swelling power and solubility, paste viscosity, retrogradation, flow and viscoelastic properties, paste clarity and freeze-thaw stability.

There have been quite some publications reporting on the properties of cassava (Charles et al, 2005; Taiwo, 2006; Camargo et al, 1988) and cocoyam (Lu et al, 2005; Sefa-Dedeh and Kofi-Agyir, 2002; Shiraishi et al, 1995) starches but only a few (Gunaratne and Hoover, 2002) have compared the properties of these two starch materials. This study was aimed at comparing the properties of cassava and cocoyam starches with a view to determining their applications in food systems and industry.

\subsection{Materials and methods}


2.1 Proximate analysis. Quantitative estimation of moisture, ash and amylose were determined by standard methods as described in IITA laboratory manual (1995). Nitrogen was determined by the method of Okalebo et al, (1993). The $\mathrm{pH}$ was measured according to the method of Camargo et al, (1988) with a Jenway pH meter; model 3015. 2.2 Microscopy of starches. Granule micrographs were obtained with a JSM 35 Genie Scanning Electron Microscope (SEM). The starch was sprinkled onto a double-backed adhesive carbon tab stuck to a circular aluminum stub. The aluminum stub with the starch sample on it was placed in the vacuum chamber of a Polaron PS 3 sputter coater, after attaining a vacuum of 0.1 to 0.2 torr and plasma current of $42 \mathrm{~mA}$, gold coating process was carried out for 140 seconds. The stub with gold coated starch was then placed in the SEM chamber which was evacuated before the electron beam was turned on. A $10 \mathrm{kV} /$ 2.05A setting was used for the subsequent imaging work on starch, the aperture size being fixed at 3 .

2.3 Gelatinization studies. Gelatinization enthalpy of starch was studied with a differential scanning calorimeter (Micro DSC III, Setaram Instruments) at 10\% starch dispersion heated from $25^{\circ} \mathrm{C}$ to $90^{\circ} \mathrm{C}$ at a scanning rate of $0.5^{\circ} \mathrm{C} / \mathrm{min}$.

2.4 Physicochemical properties. The swelling power and solubility were determined by the methods of Konik et al, (1993) and Gudmundsson and Aliasson (1991) in a thermostatic Clifton water bath at temperature range $50^{\circ}$ to $95^{\circ} \mathrm{C}$.

The pasting characteristics were determined using a Brabender viscoamylograph (Brabender Type 801203. Duisburg, Western Germany). An 8\% starch (db) slurry of cassava and cocoyam starches in distilled water, was heated from $30^{\circ} \mathrm{C}$ to $95^{\circ} \mathrm{C}$ at spindle speed of $75 \mathrm{rpm}$. It was kept at this temperature for 30 minutes and then cooled to $50^{\circ} \mathrm{C}$. 
The heating and cooling rate was $1.5^{\circ} \mathrm{C}$ per minute. The stability value and average slope of the viscosity curves during 30 minutes holding at $95^{\circ} \mathrm{C}$ were measured to compare the shear thinning properties of the starch pastes. The paste clarity and freeze-thaw stability were determined by to the methods of Singhal and Kulkarni (1990).

Rheological properties. The flow properties of the starch pastes were measured using a controlled stress Rheometer (AR 2000, TA Instruments Ltd) with cone and plate geometry (40 mm, $2^{\circ}$ cone and $52 \mu \mathrm{m}$ gap). Measurements were carried out at $25^{\circ} \mathrm{C}$ and shear rates of $10^{-1}$ to $120 \mathrm{~s}^{-1}$. The TA Data Analysis software (version VI.2.5) was used to fit shear stress versus shear rate models viz; Newtonian, Power law, Bingham, Casson and Herschel Bulkley to the experimental data. The goodness of fit for each model was evaluated using the standard error of estimate. A model was considered acceptable if the standard error is about 20 or less, and the model that has the lowest standard error was considered better than others and therefore, best suited for the description of the shear stress- shear rate profile of the starch pastes.

The viscoelastic properties were determined by carrying out a frequency sweep in the range of $10^{-1}$ to $120 \mathrm{rads}^{-1}$ within the viscoelastic region (strain, $0.01 \%$ ). The linear viscoelastic region was obtained by performing a stress sweep within the range of 0.01 to $50 \mathrm{~Pa}$ at an angular frequency of $2.683 \mathrm{rads}^{-1}$. The TA Data Analysis software (version VI.2.5) was used to obtain the storage modulus (G') and loss modulus (G”) of the starch pastes.

\subsection{Results and Discussion}

3.1 Proximate composition. The compositions of cassava and cocoyam starches are shown in Table 1. The moisture contents of both starches are within the 10 to $20 \%$ 
moisture level recommended for commercial starches (Soni et al, 1993). The ash contents of cassava $(0.29 \%)$ and cocoyam $(0.09 \%)$ are low, and within the limit $0.5 \%$ recommended for grade A industrial starches (Radley, 1976). The starches are low in nitrogen; however, cassava starch is slightly higher in nitrogen content. Cassava and cocoyam starches differed in their amylose content. Differences in amylose content have been reported to result in differences in starch physicochemical properties (Schoch and Maywald, 1968). The granules of cassava and cocoyam starches are of intermediate sizes. While the granules of cassava starch are round or kettledrum shaped with smooth surfaces, those of cocoyam are mostly indented (Figure 1). The granules of cassava starch ranged from $2.81-14.03 \mu \mathrm{m}$ with an average size of $8.42 \pm 3.35 \mu \mathrm{m}$ while the granules of cocoyam starch ranged from $3.70-10.50 \mu \mathrm{m}$ with an average granule size of $6.54 \pm 2.23 \mu \mathrm{m}$. The granules of cassava starch are generally larger than those of cocoyam starch. The $\mathrm{pH}$ of the starches is within the acceptable range for food starches (Shipman, 1967).

\subsection{Gelatinization temperature}

The temperature at which heated starch granules in water dispersion undergo transition from the crystalline state to a gel can be measured by use of a DSC. This temperature usually called gelatinization temperature is very important property in starch characterization, and if determined under a defined condition, the gelatinization temperature range is characteristic of starch type and heterogeneity in the granule population. Since individual starch granules undergo gelatinization at a specific temperature within the range, the gel endotherm obtained is broad from which the onset temperature $\left(\mathrm{T}_{\mathrm{o}}\right)$, peak temperature $\left(\mathrm{T}_{\mathrm{p}}\right)$ and completion temperature $\left(\mathrm{T}_{\mathrm{c}}\right)$ can be determined. Figure 2 shows the gelatinization endotherm of $10 \%$ aqueous dispersion of 
cassava and cocoyam starches while the gelatinization parameters are shown in Table 2 . Cassava starch gelatinized at a lower temperature range $\left(60.11^{\circ}-72.67^{\circ} \mathrm{C}\right)$ compared with cocoyam $\left(72.96-80.25^{\circ} \mathrm{C}\right)$. Gelatinization range has been reported to be dependent on difference in degree of heterogeneity of crystallites within the starch granules (Gunaratne and Hoover, 2002). The wider gelatinization range of cassava starch relative to cocoyam starch indicates greater heterogeneity of crystallites within the cassava starch granule population. The higher endothermic melting enthalpy of cocoyam starch compared with cassava starch indicates its tighter granule structure.

3.3 Swelling power and solubility. The swelling power and solubility were studied to understand the nature of intra-granular bonds. When cassava and cocoyam starches were heated in water suspension to progressively higher temperatures, the starches exhibited different swelling (Figure 3) and solubility (Figure 4) profiles. Difference in swelling and solubility profiles indicate difference in the bonding forces within the starch granules. These bonds relax with increase in thermal agitation causing the starch granules to imbibe water, swell, and the low molecular weight amylose solubilize and leach out into the aqueous medium (Balagopalan et al, 1988). Cassava starch exhibited weak intragranular organization as indicated by its low temperature relaxation $\left(60^{\circ} \mathrm{C}\right)$ and its rapid swelling at lower temperatures. Cocoyam starch, on the other hand, exhibited a tight granular organization as indicated by its high relaxation temperature $\left(75^{\circ} \mathrm{C}\right)$ and less rapid swelling. The swelling power of cassava was 1.6 times that of cocoyam at $95^{\circ} \mathrm{C}$. Though cassava and cocoyam differed widely in their swelling powers, 31.28 and 19.38 respectively, at $95^{\circ} \mathrm{C}$; their solubilities 18.89 and 18.79 were similar at $95^{\circ} \mathrm{C}$. As seen from the swelling and solubility profiles, cocoyam starch granules had tight 
heterogeneous intra-granular organization in which most of the bonding forces required energy supplied in the temperature range 75 to $80^{\circ} \mathrm{C}$ to cause relaxation.

\subsection{Pasting characteristics}

The Brabender amylograph paste viscosity analysis of the $8 \%(\mathrm{db})$ cassava and cocoyam starch slurries is presented in Table 3, while the pasting curves are presented in Figure 4. Cassava starch started gaining viscosity at $68^{\circ} \mathrm{C}$ and rose rapidly to a peak viscosity of $845 \mathrm{BU}$ at $78^{\circ} \mathrm{C}$ while cocoyam starch started gaining viscosity at $78^{\circ} \mathrm{C}$ and attained a peak viscosity of $630 \mathrm{BU}$ at $91^{\circ} \mathrm{C}$. The lower pasting temperature and rapid rise in viscosity to peak of cassava starch relative to cocoyam starch indicates a weak granular structure (Ciacco and D'Appolonia, 1977). The cold paste viscosity of cocoyam (1024 BU) was higher than that of cassava (640 BU) and this shows that cocoyam starch paste has a superior thickening property than cassava. Cocoyam starch paste $(\mathrm{C} / \mathrm{P}=0.65)$ was more stable to share thinning than cassava starch paste $(C / P=0.39)$. This indicates that cocoyam starch paste has more capacity to withstand severe processing conditions than cassava starch paste. The setback ratio of cocoyam starch paste $(\mathrm{C} / \mathrm{H}=2.50)$ was higher than that of cassava $(\mathrm{C} / \mathrm{H}=2.0)$, indicating a higher retrogradation rate in cocoyam starch dispersion due to the association of leached out amylose molecules. This property of cocoyam starch makes it suitable for use in jelly foods.

\subsection{Flow properties}

The shear stress- shear rate profiles of cassava and cocoyam starch pastes are presented in Figure 6. The best shear stress-shear rate model for describing the flow characteristics of the starch pastes was the Herchel-Bulkley model $\left(\sigma=\sigma_{Y}+\eta \dot{\gamma}^{\mathrm{N}}\right)$. The estimated parameters from the Herschel-Bulkley model fitting are presented in Table 4. The rate 
index for the two starch pastes were less than 1 indicating their pseudoplastic behaviour. Zhao et al, (2007) and Mohd. Nuru et al, (1999) have reported similar results for other starch pastes. The higher rate index of cocoyam starch paste shows that its stability to shear thinning is higher, thereby confirming the result obtained from paste viscosity analysis. The higher yield stress of cocoyam starch shows that the paste has a higher initial resistance to flow and is, therefore, more structured or rigid than the cassava starch paste.

\subsection{Viscoelastic properties}

The dynamic frequency sweep for cassava and cocoyam starch pastes is presented in Figure 7. Both the storage and loss moduli ( $\mathrm{G}^{\prime}$ and $\left.\mathrm{G}^{\prime \prime}\right)$ increased with increase in angular frequency. The storage modulus of each starch paste was higher than the loss modulus, a characteristic of gels. The G' of cocoyam starch paste was higher at all points than that of cassava. This indicates presence of higher macromolecular chain rigidity in cocoyam starch paste compared with cassava. This observation is in agreement with the result in the paste viscosity analysis where cocoyam starch paste exhibited higher stability to shears compared with cassava starch paste. The $\mathrm{G}^{\prime}$ of starch pastes has been reported to be affected by the rigidity of starch granules (Han et al, 2003; Tsai et al, (1997). Case et al, (1998) have reported positive correlation between $\mathrm{G}^{\prime}$ and amylose content which agrees with our result. The loss modulus of cocoyam and cassava starch pastes did not show any significant difference.

\subsection{Paste clarity}

Figure 8 shows that at all concentrations ranging from 0.5 to $4.0 \%$, cassava starch exhibited higher paste clarity than cocoyam starch. This is in agreement with the fact that 
starches with higher swelling power and lower retrogradation tendency have higher paste clarity (Ciacco and D'Appolonia, 1977). The general decrease in clarity observed with cocoyam starch paste is as a result of increased retrogradation arising from increased reassociation of released amylose molecules, which accompanied increase in starch concentration. Cassava starch paste however exhibited a decrease in clarity with increase in starch concentration up to $2.0 \%$ and increased again as starch concentration increased further. This observation with cassava starch paste could be due to a change in mechanism of retrogradation at starch concentrations above $2.0 \%$ as a result of interaction between the bulkier amylose and amylopectin molecules in starch reflecting their high molecular weight and possible degree of branching (Wurzburg, 1986).

\subsection{Freeze-thaw stability}

From Figure 9, it can be seen that percentage syneresis increased with number of days of freeze-thaw cycles until a maximum exudate was achieved. Cassava starch paste exhibited higher freeze-thaw stability than cocoyam starch paste and achieved maximum exudates of $31.3 \%$ as against $47.4 \%$ of cocoyam starch paste at the $13^{\text {th }}$ freeze-thaw cycle. The lower freeze-thaw stability of cocoyam starch is in line with its higher amylose content and retrogradation tendency (Ciacco and D'Appolonia, 1977).

\subsection{Conclusion}

Some properties of cassava and cocoyam starches were studied and compared. Cocoyam starch granules were generally smaller than those of cassava starch. Cocoyam starch also had higher amylose content compared with cassava starch. The gelatinization temperature and the endothermic gelatinization enthalpy were higher in cocoyam than cassava. The swelling and solubility patterns indicated lower relaxation temperature, higher swelling 
and solubilization rates in cassava starch compared with cocoyam starch. The pasting characteristics of $8 \%(\mathrm{db})$ starch slurry showed that cassava had higher peak viscosity but lower stability and setback ratios compared with cocoyam. This indicates that cocoyam starch paste is better in withstanding processing conditions and would present a superior thickening characteristic than cassava starch paste. The flow properties of both starch pastes showed non-Newtonian behaviour and could be best described by the HerschelBulkley model. The storage modulus of cocoyam starch paste was higher than that of cassava indicating that cocoyam starch paste was more rigid than cassava starch paste. Cassava starch paste exhibited higher paste clarity and freeze-thaw stability than cocoyam starch paste.

\section{References}

Balagopalan, C., Padmaja, G., Nanda, S.K. and Moorthy, S.N. 1988. Cassava in Food, Feed and Industry. CRC Press Inc. Boca Raton, Florida, p126-127.

CBN (1995). Central Bank of Nigeria Statistical Bulletin, Volume 6, No. 2, p. 122.

Camargo, C., Colonna, P., Buleon, A. and Richard-Molard, D. 1988. Functional properties of sour cassava (M. utilisima) starch: Polvilho Azedo. Journal of Science of Food and Agriculture, 45 (3), 273-289.

Case, S.E., Capitani, T., Whaley, J.K., Shi, Y.C., Trzascko, P., Jeffcoat, R. and Goldfarb, H.B. 1998. Physicochemical properties and gelation behaviour of a low-amylopectin maize starch and other high-amylose maize starches. Journal of Cereal Science 27, 301314. 
Charles, A.L., Chang, Y.H., Ko, W.C., Sriroth, K. Huang, T.C. 2005. Influence of amylopectin structure and amylose content on the gelling properties of five cultivars of cassava starch. Journal of Agriculture and Food Chemistry, 53 (7), 2717-25.

Ciacco, C.F. and D'Appolonia, B.K. 1977. Characterization of starches from various tubers and their use in bread making. Cereal Chemistry 54: 1096-1107.

FAOSTAT (2001). http://www.fao.org

Gudmundsson, M. and Alliasson, A-C. 1991. Gel volume and amylose leaching. Cereal Chemistry, 68 (2), 172-177.

Gunaratne, A. and Hoover, R. 2002. Effect of heat-moisture treatment on the structure and physicochemical properties of tuber and root starches. Carbohydrate Polymers 49, 425-437.

Han, X-Z., Campanella, O.H., Guan, H., Keeling, P.L. and Hamaker, B.R. 2003. Influence of maize starch granule-associated protein on the rheological properties of starch pastes. Part II. Dynamic measurements of viscoelastic properties of starch pastes. IITA Laboratory Manual. 1995. Methods for Maize Quality Evaluation. (A.U. Okorowa, Compiler), International Institute of Tropical Agriculture Press, Ibadan, Nigeria.

Konik, C.M., Kiskelly, D.M. and Gras, P.W. 1993. Starch: Swelling power, grain hardness and protein. Relation to sensory properties of Japanese noodles. Starch/Starke 45 (4), 139-144.

Leach, H.W. 1965. Gelatinization of Starch. In Starch: Chemistry and Technology. Volume 1. R.L. Whistler and E.F. Paschal (eds), Academic Press, New York. p289-307. 
Lu, T-J., Chen, J-C., Lin, C-L. and Chang, Y-H. 2005. Properties of cocoyam (Xanthosoma sagittifolium) tubers planted in different seasons. Food Chemistry 91, 6977.

Mohd. Nuru, I., Mohd. Azemi, B.M.N. and Manan, D.M.A. 1999. Rheological behaviour of sago (Metroxylon sagu) starch paste. Food Chemistry 64 (4), 501-505.

Nweke, F. 2004. New Challenges in the Cassava Transformation in Nigeria and Ghana. EPTD Discussion Paper No. 118. Environment and Production Technology Division, International Food Policy Research Institute 2033 K Street, NW Washington, D.C. 20006 USA. [http://www.ifpri.org/divs/eptd/dp/papers/eptdp118.pdf]

Okalebo, J.R., Gathna, K.W. and Woomer, P.I. 1993. Laboratory Methods of Soil and Plant Analysis. A working Manual. TSBF Nairobi, Kenya, p22-29.

Radley, J.A. 1976. Starch Production Technology. Applied Science Publishers Ltd, London. p203-208.

Salehuzzman, S., Bleker, T., Jacobson, E. and Visser, R.G.F.1992. Cloning and characterization of starch biosynthetic genes in cassava (Manihot esculenta Crantz). In: Proceedings CBN first Int'nal Scientific Conference Meeting of the Cassava Biotechnology Network. CIAT. W.M. Roca and A.M. Thro (eds). P229-233.

Schoch, T.J. and Maywald, E.C. 1968. Preparation and properties of various legume starches. Cereal Chemistry 45, 564-573.

Sefa-Dedeh, S. Kofi-Agyir, S.E. 2002. Starch structure and some properties of cocoyam (Xanthosoma sagittifolium and Colocasia esculenta) starch and raphides. Food Chemistry, 79 (4), 435-444. 
Shipman, L. 1967. Starch: Chemistry and Technology. Volume II, R.L. Whistler (ed), Academic Press Inc. New York, p115.

Shiraishi, K., Lauzon, R. D., Yamazaki, M., Sawayama, S., Sugiyama, N. and Kawabata, A. 1995. Rheological properties of cocoyam starch paste and gel. Food Hydrocolloids, 9 (2), 69-75.

Singhal, R.S and Kulkarni, P.R. (1990) Some Properties of Amaranthus Paniculatas (Rajgeera) Starch Pastes. Starke/Starch 42 (1) 5-7.

Soni, P.L., Sharma, H., Dun, D., Gharia, M.M. 1993. Physicochemical properties of Quercus leucotrichophora (Oak) starch. Starch/Starke 45 (4), 127-130.

Taiwo, K.A. 2006. Utilization Potentials of Cassava in Nigeria: The Domestic and Industrial Products. Food Reviews International, 22 (1), 29-42.

Tsai, M.L., Li, C.F. and Lii, C.Y. 1997. Effect of granular structures on the pasting behaviours of starches. Cereal Chemistry 74, 750-757.

Wurzburg, B.O. (1986). Modified Starches: Properties and Uses. O.B Wurzburg (editor), CRC Press Inc. Boca Raton. p 4-10.

Zhao, S-m., Qiu, C-g., Xiong, S-b. and Liu, Y-m. (2007). Rheological properties of amylopectins from different rice type during storage. Journal of Central South University of Technology, 14(1), 510-513. 


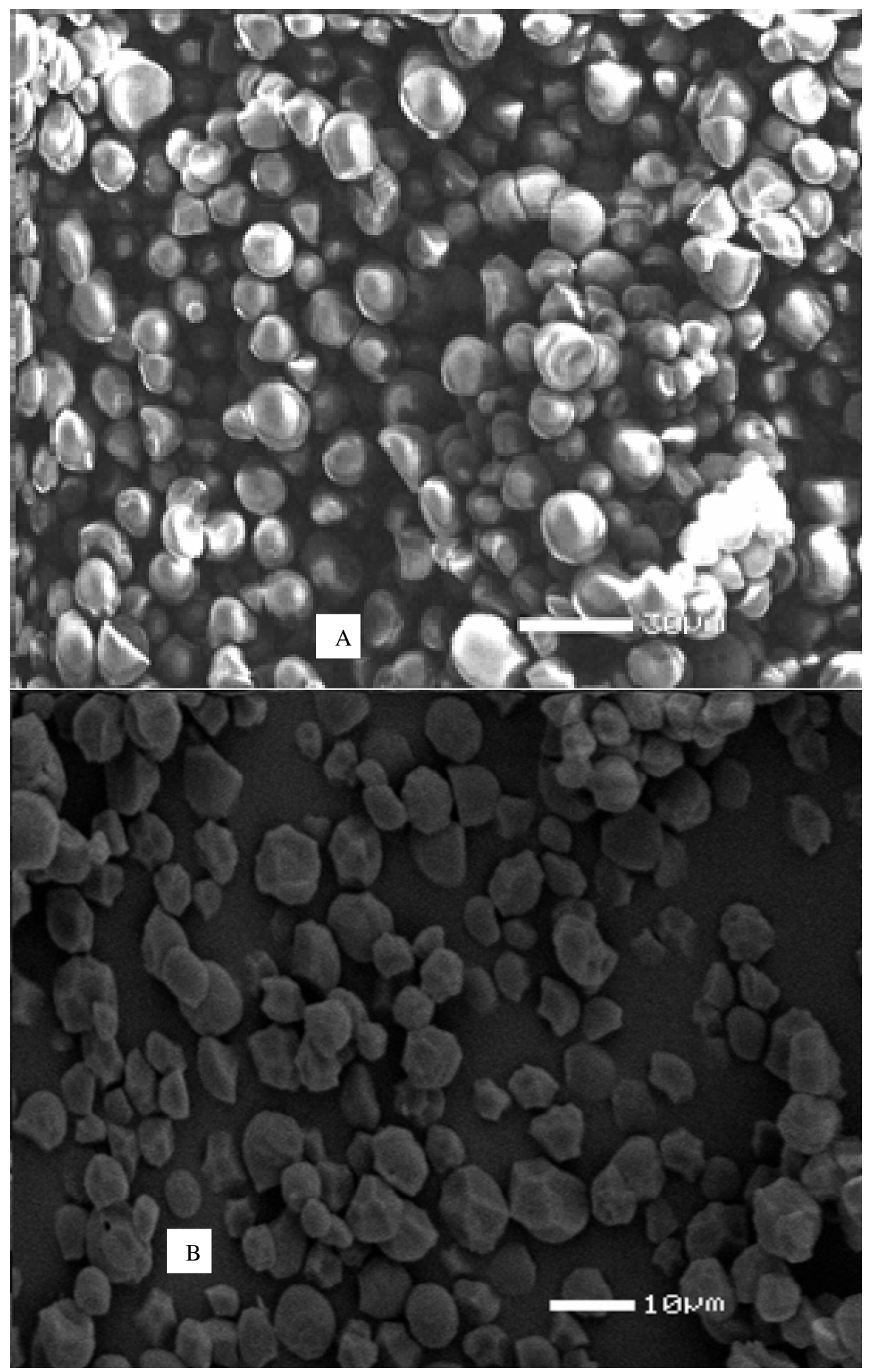

Figure 1. SEM micrographs of cassava (A) and cocoyam (B) starch granules. 


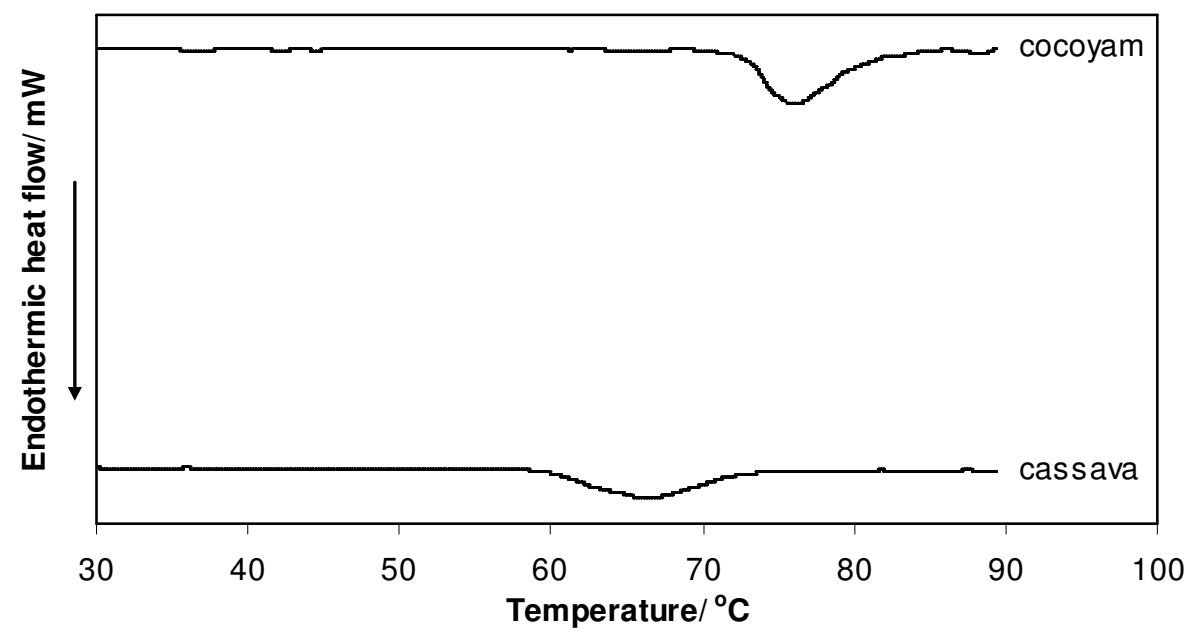

Figure 2. Differential scanning calorimetry (DSC) of $10 \%$ dispersions of cassava and cocoyam starches in distilled water

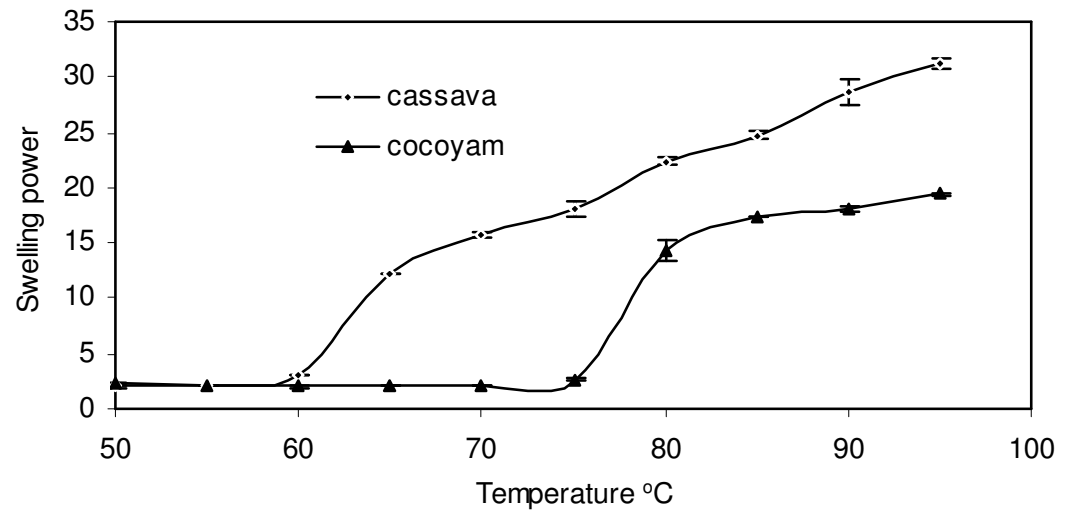

Figure 3. Sw elling pow er patterns of native cassava and cocoyam starches

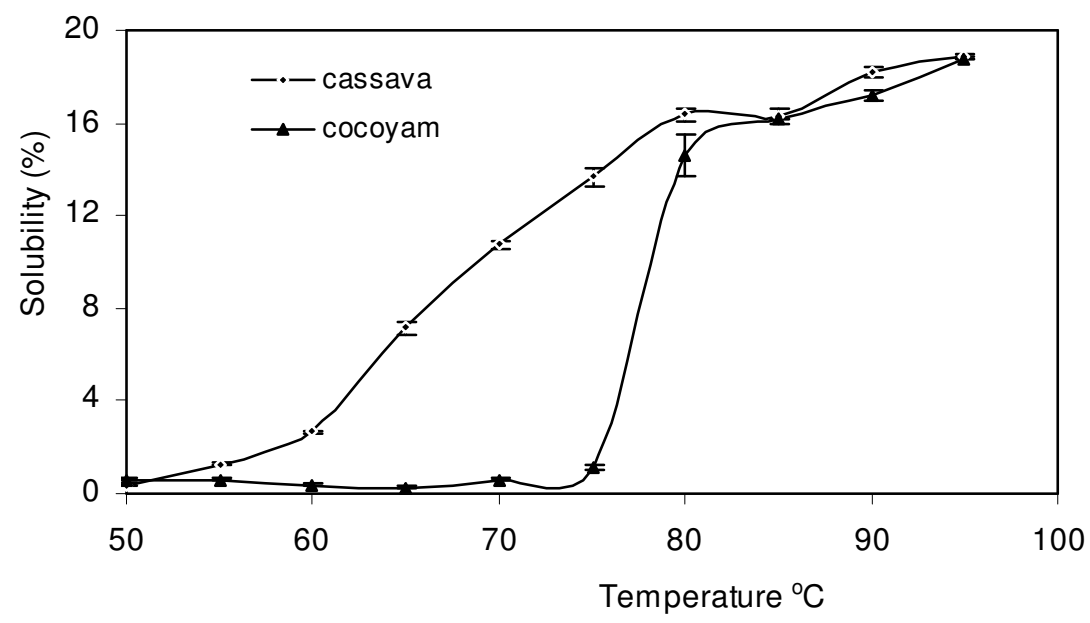

Figure 4.Solubility patterns of cassava and cocoyam starches. 


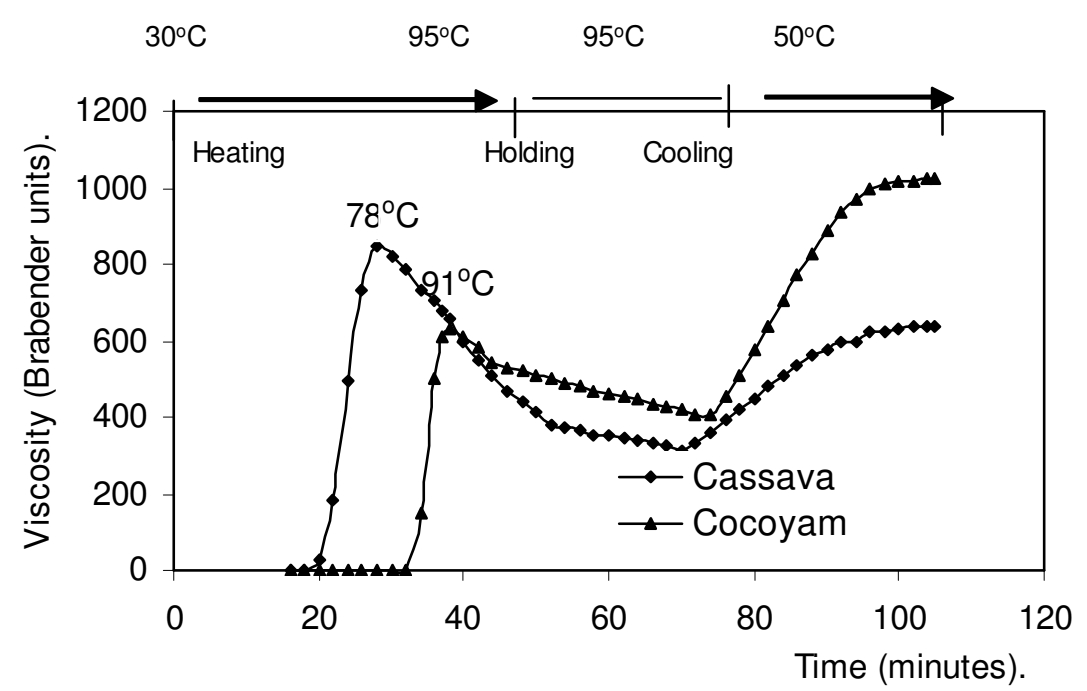

Figure. 5. Brabender amylograph paste viscosity of $8 \%$ slurry of cassava and cocoyam starches.

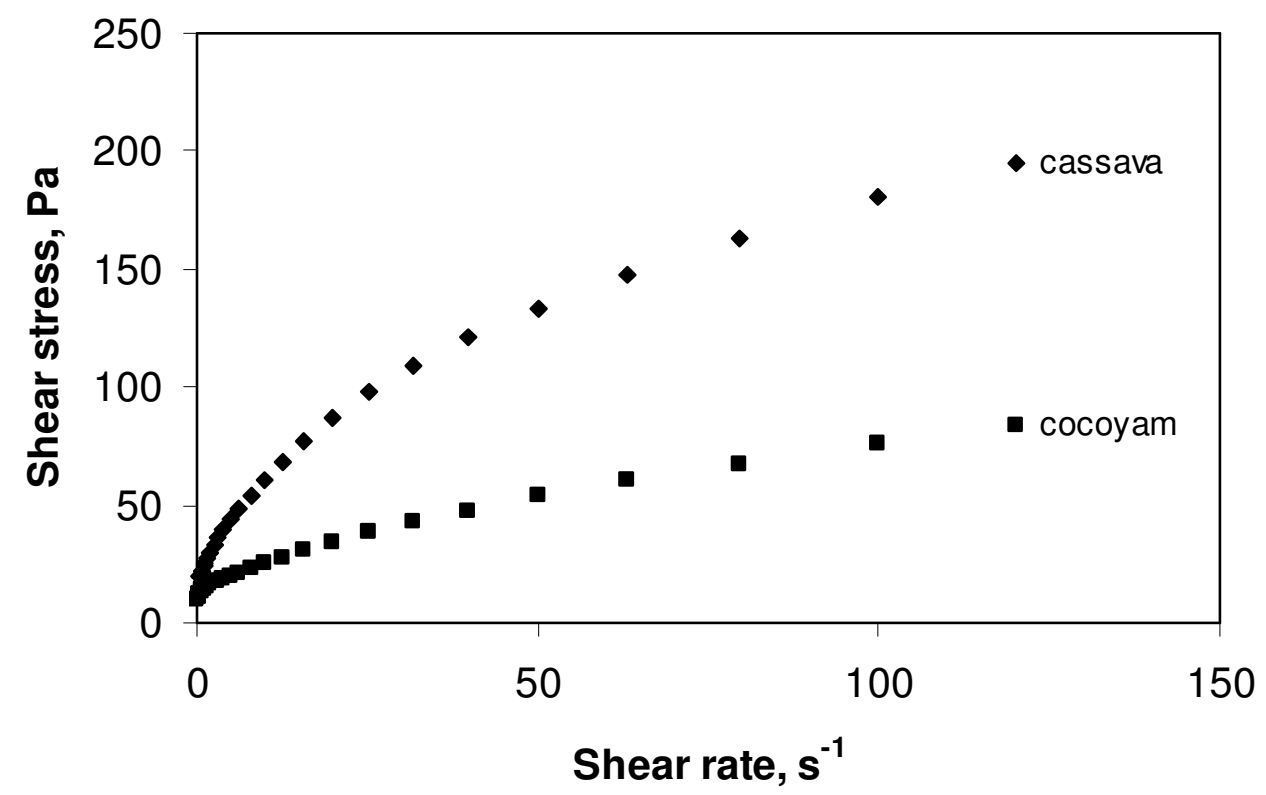

Figure 6: Shear stress-shear rate profiles for $8 \%$ gel of cassava and cocoyam starch pastes 


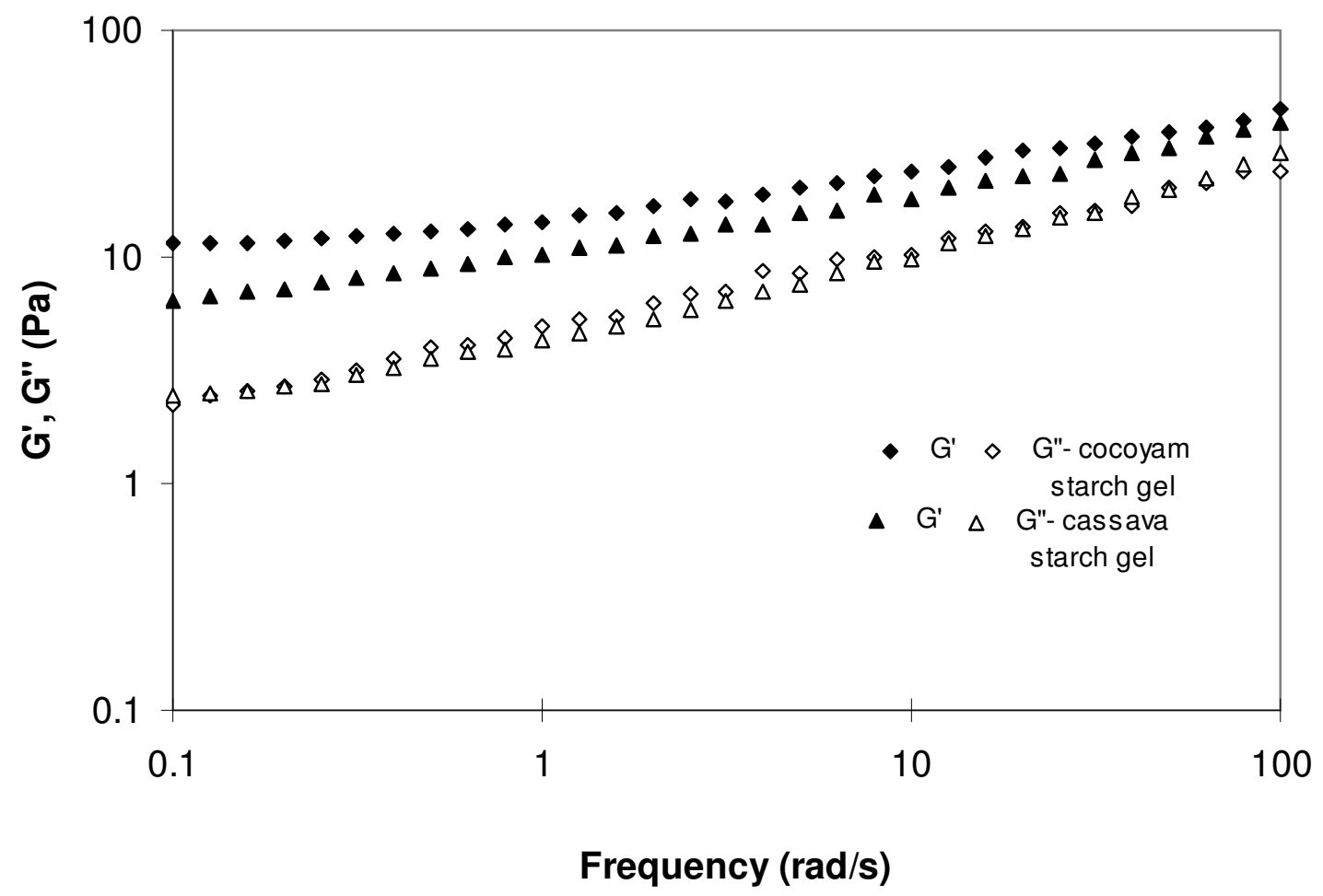

Figure 7: Dynamic frequency sweep showing G' and G" for $8 \%$ gels of cassava and cocoyam starch pastes

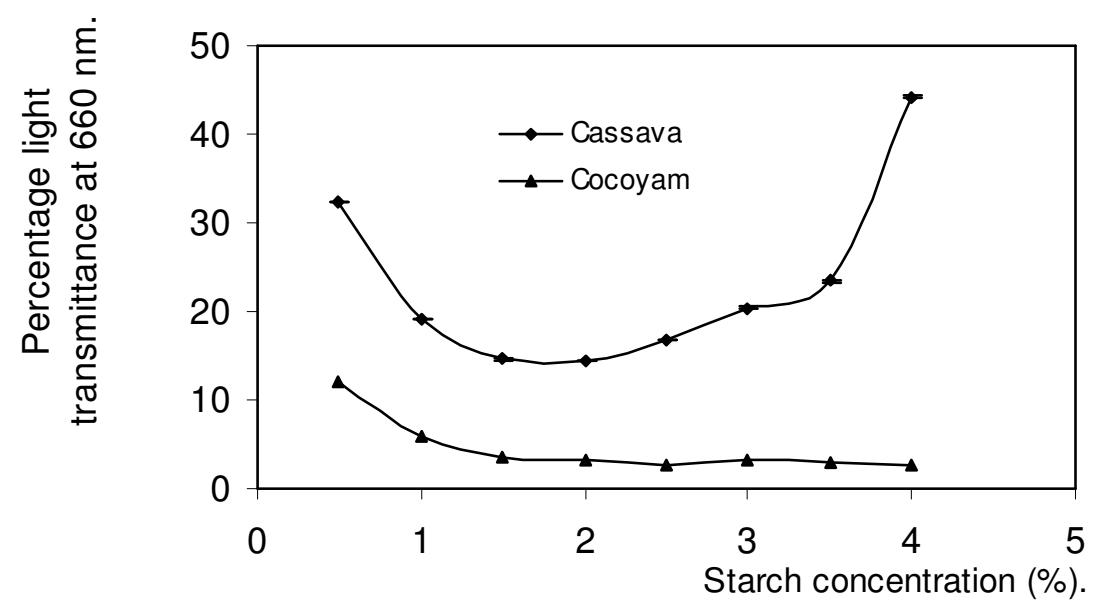

Figure 8. Paste clarity of cassava and cocoyam starch pastes. 


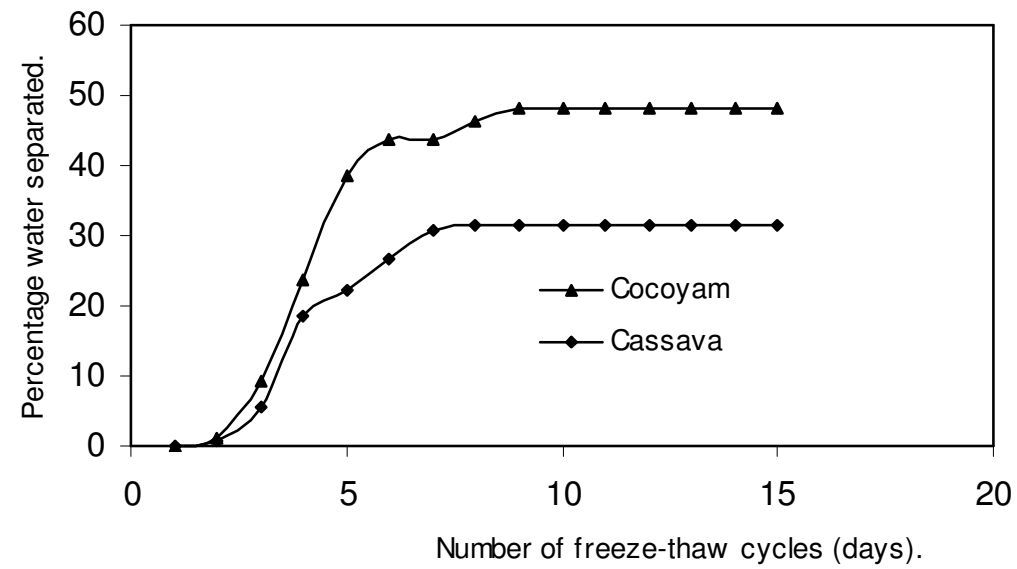

Figure 9. Freeze-thaw stability of native cassava and cocoyam starch pastes.

Table 1. Proximate composition of cassava and cocoyam starches a

\begin{tabular}{lll}
\hline Starch source & Cassava & Cocoyam
\end{tabular}

Moisture (\%)

Ash (\%)

Nitrogen (\%)

Amylose (\%)

Granule size range $(\mu \mathrm{m})$

$\mathrm{pH}$ at $25^{\circ} \mathrm{C}$

${ }^{\text {a }}$ Results are mean of three determinations.

${ }^{b}$ granule size average ( based on 30 granules).
$14.6 \pm 0.20$

$0.29 \pm 0.06$

$0.08 \pm 0.008$

$29.29 \pm 0.03$

$2.81-14.03(8.42 \pm 3.35)^{b}$

6.56
6.76

$11.8 \pm 0.05$

$0.09 \pm 0.04$

$0.06 \pm 0.004$

$33.30 \pm 0.09$

$3.70-10.50(6.54 \pm 2.13) \mathrm{b}$ 
Table 2: Gelatinization properties of cassava and cocoyam starches

\begin{tabular}{lcc}
\hline Gelatinization parameters & cassava & cocoyam \\
\hline Onset temperature, $\mathrm{T}_{\mathrm{o}}\left({ }^{\circ} \mathrm{C}\right)$ & 60.11 & 72.96 \\
Peak temperature, $\mathrm{T}_{\mathrm{p}}\left({ }^{\circ} \mathrm{C}\right)$ & 66.15 & 76.04 \\
Completion temperature, $\mathrm{T}_{\mathrm{c}}\left({ }^{\circ} \mathrm{C}\right)$ & 72.67 & 80.25 \\
Gelatinization range, $\left(\mathrm{T}_{\mathrm{c}}-\mathrm{T}_{\mathrm{o}}\right)\left({ }^{\circ} \mathrm{C}\right)$ & 12.56 & 7.29 \\
Endothermic enthalpy, $\Delta \mathrm{H}(\mathrm{J} / \mathrm{g})$ & 14.35 & 17.17 \\
\hline
\end{tabular}

Table 3. Brabender amylograph paste viscosity analysis of $8 \%$ slurry of cassava and cocoyam starches.

\begin{tabular}{lcc}
\hline \multicolumn{1}{c}{ Starch property } & Cassava & Cocoyam \\
\hline Pasting temperature $(\mathbf{T p}),{ }^{\circ} \mathrm{C}$ & 68 & 78 \\
Temperature at peak viscosity $(\mathbf{T p}),{ }^{\circ} \mathrm{C}$ & 78 & 91 \\
Peak viscosity during heating $(\mathbf{P}), \mathrm{BU}$ & 845 & 630 \\
Viscosity at $95^{\circ} \mathrm{C}$ BU & 590 & 545 \\
Viscosity after 30 minutes holding at $95^{\circ} \mathrm{C}(\mathbf{H})$, BU 320 & 410 \\
Viscosity on cooling to $50^{\circ} \mathrm{C}(\mathbf{C}), \mathrm{BU}$ & 640 & 1024 \\
Stability ratio $(\mathbf{H} / \mathbf{P})$ & 0.39 & 0.65 \\
Set-back ratio $(\mathbf{C} / \mathbf{H})$ & 2.0 & 2.50 \\
\end{tabular}


Table 4. Estimated parameters from Herschel-Bulkley fitted shear stress-shear rate profiles of cassava and cocoyam starch pastes at $25^{\circ} \mathrm{C}$

\begin{tabular}{lcccr}
\hline Parameter & $\sigma_{Y}$ & $\eta$ & $\mathrm{n}$ & s.e \\
\hline Cassava starch & 4.024 & 19.33 & 0.4815 & 10.17 \\
Cocoyam starch & 9.726 & 3.984 & 0.6110 & 5.532 \\
\hline
\end{tabular}

$\sigma_{Y}=$ yield stress $(\mathrm{Pa}), \eta=$ viscosity $(\mathrm{Pa} . \mathrm{s}), \mathrm{n}=$ rate index, $\mathrm{s} . \mathrm{e}=$ standard error. 